\title{
Sub-lethal ionizing radiation alters Foxp3 expression in CD4+ T regulatory (Treg) cells in vitro and in vivo
}

\author{
Anita Kumari, Samantha Simon, Charlie Garnett-Benson ${ }^{*}$
}

From 30th Annual Meeting and Associated Programs of the Society for Immunotherapy of Cancer (SITC 2015) National Harbor, MD, USA. 4-8 November 2015

The use of sub-lethal radiation has been shown to alter cell phenotype and gene expression. $\mathrm{T}$ regulatory (Treg) cells are phenotypically defined as being CD4+CD25+ Foxp3+ $\mathrm{T}$ cells and are known to suppress the function of CD8+ cytotoxic T lymphocytes (CTLs). Inhibiting the suppressive function of Treg cells allows for activation and proliferation of CD8+ CTLs. We examined the effects of sub-lethal radiation on Tregs 24- to 72-hrs post-treatment. We found that radiation treatment decreased the number of Treg cells however the total $\mathrm{CD} 4+\mathrm{T}$ cell fraction remained unaltered. Our data suggests that the use of sub-lethal radiation can modulate the expression of Foxp3 in CD4+ Treg cells in vitro and in vivo. Moreover, the loss of Foxp3-mediated suppressive functions may be linked to increased CTL activity.

\section{doi:10.1186/2051-1426-3-S2-P269}

Cite this article as: Kumari et al: Sub-lethal ionizing radiation alters

Foxp3 expression in CD4+ T regulatory (Treg) cells in vitro and in vivo.

Journal for ImmunoTherapy of Cancer 2015 3(Suppl 2):P269.
GSU, Atlanta, GA, USA
Submit your next manuscript to BioMed Central and take full advantage of:

- Convenient online submission

- Thorough peer review

- No space constraints or color figure charges

- Immediate publication on acceptance

- Inclusion in PubMed, CAS, Scopus and Google Scholar

- Research which is freely available for redistribution 